\title{
INVESTIGATING TOURISM DEVELOPMENT IN MACEDONIA
}

DOI: http://dx.doi.org/10.18509/GBP.2016.41

UDC: 338.48-026.23(497.7), 1956/2013“6

\author{
Associate Prof. Dr. Biljana Petrevska ${ }^{1}$ \\ Dr. Noga Collins-Kreiner ${ }^{2}$ \\ ${ }^{1}$ Faculty of Tourism and Business Logistics, Goce Delcev University - Stip, Macedonia \\ ${ }^{2}$ Department of Geography and Environmental Studies, University of Haifa, Israel
}

\begin{abstract}
The study investigates the current level of tourism development in Macedonia by applying the Tourism Area Life Cycle (TALC) model. Moreover, it assesses the validity and applicability of this model with regard to the evolution of tourism expansion. The article explores several areas of government's role in the process of tourism growth at each TALC stage. The analysis is based on secondary data sources. The results point that tourism in Macedonia is in the development stage. The general findings indicate insufficiently developed tourist supply which is a must in tourism development. Finally, the study recommends practical remarks aimed at motivating key players in the tourism arena to focus their attention on identifying an effective framework for improving their current modest results and formulating sound economic and tourism policies.
\end{abstract}

Keywords: TALC model; Tourism development; Tourism policy; Macedonia.

\section{INTRODUCTION}

Countries around the world today are designing and adopting strategies, methods, and tools aimed at attracting tourists and achieving a competitive position in the global tourism arena. Tourism, however, is influenced by a large number of social, economic, political and environmental factors resulting with extremely diversified character, which urges application of tourism planning process.

The article employs Butler's [1] Tourism Area Life Cycle (TALC) model as a framework of analysis, but pays particular attention to the role of government influence during each stage of tourism development in Macedonia. Its main contribution lies in its highlighting of the connection between the government's role in policy-making on the one hand, and each TALC stage on the other hand, in an effort to provide a better understanding of the complexity of tourism development at its different stages.

The study has two goals: (1) To ascertain Macedonia's tourism life cycle and to identify country's current stage of development; and (2) To explore the government's role in policy-making and planning regarding tourism development. To achieve these goals, the article assesses the validity and applicability of the TALC model with regard to the evolution of tourism development in Macedonia and attempts to disentangle the involvement of government in shaping tourism development in the country. The next section offers a brief overview of the literature on TALC model and tourism development, and section three provides selected stylized facts on the current state of tourism development in Macedonia. Section four addresses the study's methodology and research frame, and section five presents our main research findings and discussion. The article's final section offers practical remarks aimed at motivating key players in the tourism arena 
to focus their attention on identifying an effective framework for improving their current modest results and formulating sound tourism policy.

\section{LITERATURE REVIEW}

The literature contains a large body of work exploring the TALC model, which was first advanced by Butler [1] and explains the evolution of tourism, breaks the process down into the phases of exploration, involvement, development, consolidation, and stagnation, followed alternatively by either decline or rejuvenation, resulting in a logistic S-curve. This classical model it is fully applicable to already established destinations with long life spans [2] and is often understood as an ideal model of evolution [12]. It helps to assess the evolving character of tourism areas and assists in explaining and addressing cycles of economic growth in tourism-dependent areas with environmental constraints [8]; marketing perspectives [9]; economic, social, and environmental issues [6]; different types of entrepreneurs [10]; and spatial interaction [5].

Tourism development has been greatly influenced by government involvement [4] and [7]. Some studies explore the impact of the context of economic and social renewal in the aftermath of political conflict on tourism development by exploring the case of Bosnia and Herzegovina [3].

\section{CURRENT TOURISM DEVELOPMENT IN MACEDONIA}

Macedonian authorities identified tourism sector as a possible means of micro and macroeconomic impact of various kinds, with potential to promote important economic goals, such as enhancing the foreign export demand for domestic goods and services, generating foreign currency earnings and new employment opportunities, contributing to the repayment of foreign debt, and increasing national revenue.

The total number of tourists in the country has continued to rise. Of the 735,650 tourists in Macedonia in 2014, 310,336 (42\%) were domestic and 425,314 (58\%) were foreign. The year 2014 recorded a total of 2,195,883 overnight stays, with 1,273,370 (58\%) accounted for by domestic tourists and 922,513 (42\%) by foreign tourists. The third quarter of the year (July-September) was clearly dominant in terms of arrivals, accounting for $43.3 \%$ of all recorded arrivals in the country in 2014. The general average length of stay was 3 days (4.1 days for domestic tourists and 2.2 days for foreign tourists). In addition to the increased interest of tourists from Turkey, the Netherlands, and Poland, Macedonia's foreign tourists generally come from neighboring countries such as Greece, Serbia, Bulgaria, and Albania.

\section{METHODOLOGY AND RESEARCH FRAME}

The research applied qualitative analysis based on reviewing and investigating the relevant secondary sources (statistical data, historical and contemporary written sources, and scientific publications). The total annual tourist arrivals constitute the primary unit of measure for tourism development. The data set covers the period 1956-2013. However, in order to enhance the understanding of the topic at hand, we broke down this overall period into two sub-periods, each with its own Tourism Area Life Cycle:

Sub-Period I (1956-1990), when Macedonia was still an integral part of Yugoslavia; and Sub-Period II (1991-2013) covers more than two decades following independence.

Throughout both periods, we conducted a detailed assessment of several key areas of government influence on tourism, such as privatization, legislation and tourism promotion. 


\section{ANALYSIS, FINDINGS AND DISCUSSION}

The analysis starts with identifying Macedonia's tourism life cycle (Figure 1). The visual impression allows us to reach an important conclusion that Macedonia's life cycle curve exhibits a double cycle sequence known as a cycle-recycle pattern [11].

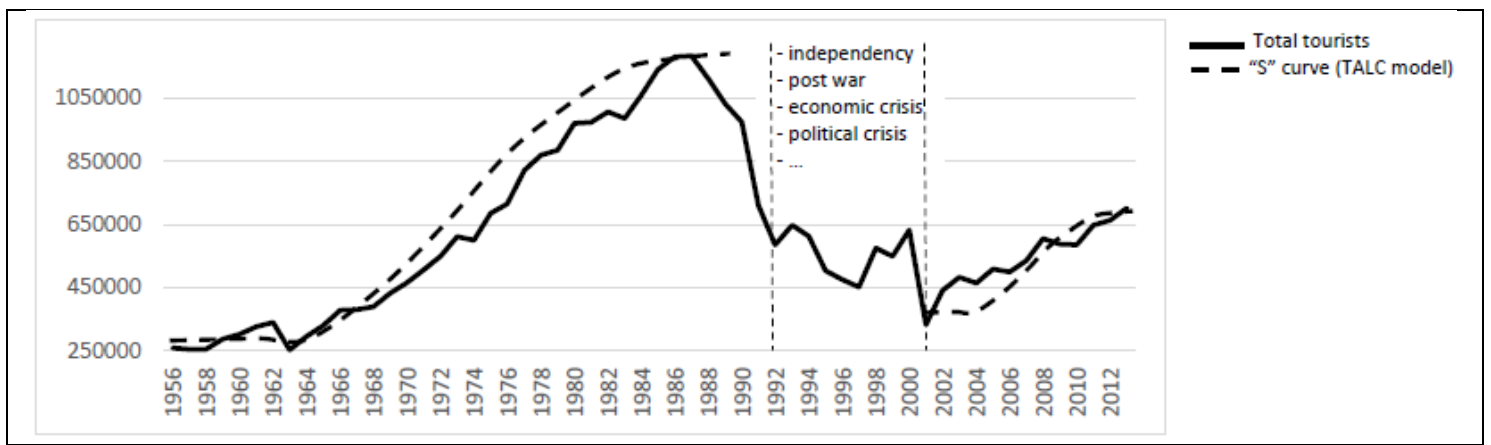

Figure 1. Macedonia's Tourism Life Cycle, 1956-2013

To acquire additional in-depth knowledge on the research question, we divided the sample period into two sub-periods and determined TALC curves for each. The period 19912001 can be considered a transitional stage in that it reflects both the decline of the first cycle and, as the period following the independence of Macedonia, the beginning of the second cycle. It was during this period that the previous cycle was discontinued by serious events that had profound negative effects on Macedonia's economy (such as wars in neighboring Serbia, bomb attacks on Kosovo, a refugee crisis, the establishment of a new monetary system and currency, the transformation from a planned to a free-market economy, ethnic-conflicts, political crisis, etc.). This interval was deliberately excluded from the analysis due to fact that during these years, as a result of the above noted circumstances, Macedonia was not perceived as a safe tourist destination. As a result, it was extremely difficult if not impossible to acquire reliable statistics for this period.

Figure 2 reflects that the life cycle for the sub-period I (1956-1990) fully conforms to the classic TALC model and consists of all the phases (exploration, involvement, development, consolidation, stagnation, and decline).

Before 1956, Macedonia was characterized by an administrative and central planning system of management, and the goals, aims and objectives of tourism development were focused on domestic tourism. During this period, the government played an active role, and the investment policy generally focused on increasing the capacities of public hotels and establishing catering services and restaurants for the working class. In an effort to support domestic tourism, the government introduced certain reductions in communication taxes.

The first exploration stage (1956-1960) is characterized by a workers' self-government management system characterized primarily by the absence of private ownership. The resulting reduced labor productivity had a spill-over effect on overall socioeconomic activity. The main focus was on individual mass tourists attracted as individuals for independently organized visits. Local residents were not involved and the effects on the national economy were minimal. The total number of tourists was low and there were no public facilities, resulting in a tourism demand that was 30 to $50 \%$ lower than in the involvement stage. 


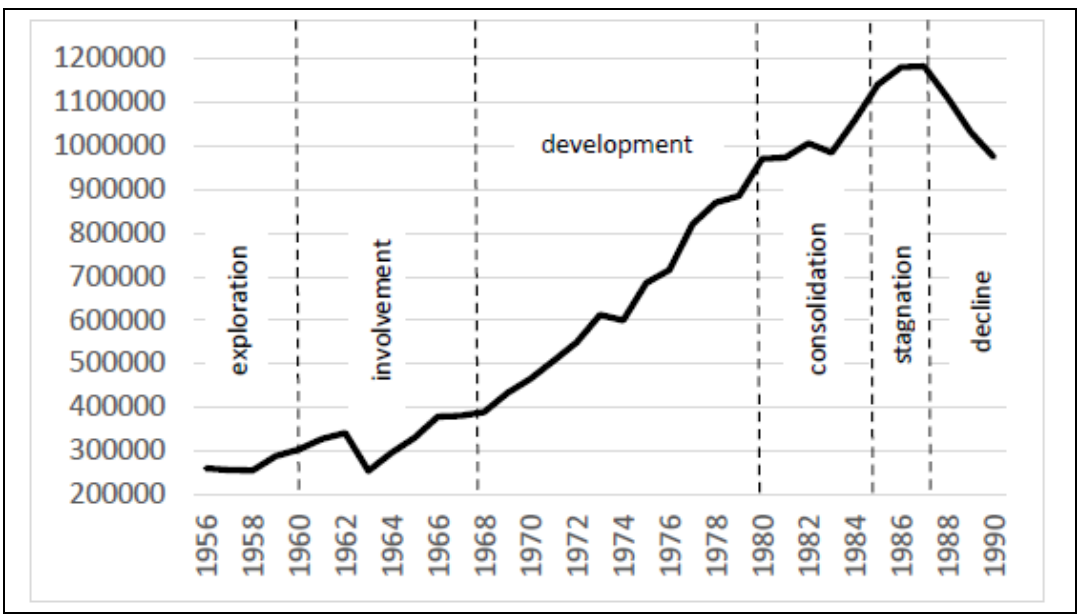

Figure 2. Macedonia’s Tourism Life Cycle, Sub-Period I (1956-1990)

During the involvement stage (1961-1968), the number of tourists grew primarily due to the government's initiation of various measures and activities for introducing an "opendoor" and "good-neighbor" policy. The government also built many new accommodation facilities, educated and trained personnel for the tourism industry, invested in tourism infrastructure, allowed free market price policy, offered domestic tourist discounts, introduced subsidies to hospitality, granted capital tourism investments, invested in the enhancement of international tourism flow, and other such measures. In 1963 a catastrophic earthquake destroyed the Macedonian capital city of Skopje, which explains the decline in the number of total tourist arrivals. During this period, the government lacked a clearly defined long-term tourism policy and addressed tourism obstacles in a partial and unsynchronized manner by means of short-term ad-hoc measures.

During the development stage (1969-1980), tourism was identified as a priority sector and the government began to engage in significant intervention, including the introduction of tax incentives for stimulating the construction of new tourism facilities, loans, credits, funds for regional development, and other such measures. The main goal during this stage was to initiate and stimulate positive tourism development outcomes which resulted in significant increase in tourist arrivals.

During the consolidation stage (1981-1985) the total number of tourists grew by $30 \%$ in comparison to the development phase, indicating the full development of tourism functions. This period is characterized by activities and measures aimed at encouraging the development of foreign tourism, such as the provision of financing for promotion expenses; favorable credit for the construction of accommodation facilities for less developed municipalities; the stimulation of foreign exchange earnings; and enrichment of the tourism supply.

The short period spanning the years 1986-1988 marked the stagnation stage when tourism reached its height of 1.2 million tourists before entering into decline stage (1989-1990), which marked the final stage of the TALC experienced by Macedonia prior to independence. It was characterized by a decline in the total number of tourists (an average of $6.4 \%$ ), decreasing tourist expenditures, a drop in the quality of tourist product, social problems, instability in the surrounding region, negative political conditions (national and regional), and threats posed by numerous other exogenous factors. The decline in this case was the result of the beginning of the armed conflict among the components of the state of Yugoslavia which ended in its disintegration. 


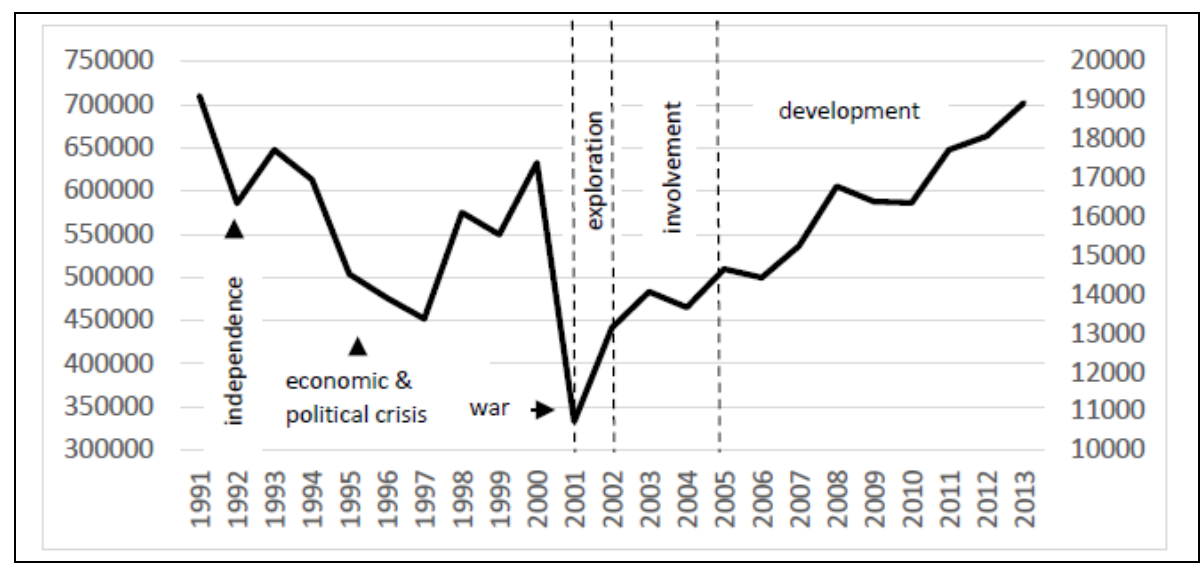

Figure 3. Macedonia's Tourism Life Cycle, Sub-Period II (1991-2013)

Figure 3 illustrates the life cycle of Macedonia for the second sub-period (1991-2013), which represented more than twenty years of independence. As earlier discussed, the interval 1991-2001 is deliberately excluded from the analysis due to the destructive effect of a large number of major destabilizing events that discontinued the cycle (collapse of former Yugoslavia, the transition process, various reforms, political instability, armed conflicts in neighboring countries, economic crisis, sanctions, blockades, internal ethnic conflicts, socioeconomic restructuring, etc.). For this reason, the second cycle curve for this sub-period begins only after 2001. In contrast to the previous sub-period I in which Macedonia's life cycle fully conformed to all the stages of the classic TALC model, this second sub-period contained only three stages: exploration, involvement, and development (Figure 3).

During the exploration stage (2001-2003), tourism was characterized by low publicity, resulting in scarce visitation. Tourism infrastructure and facilities were inadequate, advertising was unconvincing, and the tourist activity growth rate was low and based chiefly on individual trips. The country also suffered from a lack of specific tourismoriented services. Overall, tourism had no substantial impact on the lives of residents.

During the involvement stage (2004-2005), tourism awareness increased significantly among the local population and tourism actors, helping shape the tourism market in the first line by increasing the international tourist arrivals. The local environment also improved significantly, which also contributed to the expansion and enhancement of the tourism facility.

The development stage (2005-2013) was characterized by a progressive increase in the number of tourists, attracted by persuasive advertising and increased promotion. Auxiliary tourism facilities and services also improved and investments were made in new ventures. Tourism services and activities began to grow at a quicker pace, new services were provided in the form of organized trips, and tourism in the country began to have an impact on local residents. Addressing this situation has required the creation of a comprehensive and well-designed supply of diversified tourism products by including various events associated with culture and tradition, which has also served to promote the country as an attractive tourism destination for the surrounding region. This enhancement of the tourism supply has contributed to increases in the number of total tourists and overnights, the average length of stay, reduced seasonality, and the promotion of sustainable development. In particular, the increased number of foreign tourists has helped introduce various events of local, regional, and national character, with an eye toward their international expansion. Also during the development stage, the government 
significantly changed its role in a qualitative manner, by continuing intervention but limiting it only to certain high priority areas such as funding tourism promotion, crediting capital tourism capacities, stimulating tourism income, enhancing tourism supply, and initiating tourism networking.

Macedonia has not reached the consolidation stage and is therefore yet to experience stagnation. However, this may begin when the rate of tourists' visits starts to decrease, despite growing in absolute figures. During this phase, the number of tourists may exceed the number of inhabitants, at least at some times of the year, pointing to the presence of a tourism-based economy. This would also mean that tourism is economically important for the destination, but that the growth rates are low. Generally, in these final stages, the tourism market is saturated and the introduction of innovative itineraries is a priority for the promotion of diversified tourist products. The national tourism system, therefore, is in need of strengthening supported by reminder-oriented advertising and the implementation of new strategies for tourism development through the involvement of local stakeholders.

\section{CONCLUSIONS AND RECOMMENDATIONS}

Supporting and sustaining the current development stage will require government intervention in a number of ways, particularly by fostering the evolution of a more competitive tourism sector and by facilitating systematic change through the improvement of the tourist product and the strengthening of the role of the private tourism and hospitality sector. In order to make tourism more competitive, the following fundamental strategic improvements should be instituted:

First, efforts should be made to make tourism fully recognizable and to improve the current marketing strategy. The focus should be on promotion, mainly through the introduction of new innovative approaches;

The second strategic measure recommended for improving tourism competitiveness is to strengthen the coordination between the central and local governments, in addition to other tourism players from the private sector. The objectives and aims delineated by the tourism development plans and programs must be fully implemented, regardless of the level of implementation. The expectations of all tourism suppliers must conform to the expectations of tourists and travelers who visit Macedonia. To this end, it is recommended to launch a series of Tourism Awareness Program Activities (forums and debates) to raise awareness of the importance of tourism for Macedonia's development.

Despite the indicators of positive tourism development, our findings suggest that the keyplayers must nonetheless pay close attention to overcoming the potential threats posed by the unfavorable attributes of the Macedonian tourism industry. In this way, analysis in accordance with the TALC model can help management take appropriate measures to achieve better balanced tourism development in the country.

This article underscores the importance of continuous, systematic analysis of the tourism sector as a factor to be considered by all tourism actors responsible for creating development strategies in Macedonia. The primary conclusions reflect the urgent need to undertake serious measures-including strategic planning for tourism improvement-to enhance tourism development in Macedonia in order to avert such an eventuality.

Notwithstanding the difficulties involved with using the TALC model to assess the evolution of tourism in Macedonia, this article assists in better understand the symptoms and indicators upon which the serious redesigning of the national tourism development 
strategy should be based. Overall, the research generated useful findings and points to valuable directions for further work.

\section{REFERENCES}

[1] Butler, R. The concept of a tourist area cycle of evolution. Implications for management of resources, Canadian Geographer, 24(1), pp. 5-12, 1980.

[2] Butler, R. W. Tourism in the future: Cycles, waves or wheels?, Futures, 41(6), pp. 346-352, 2009.

[3] Causevic, S. \& Lynch, P. Political (in)stability and its influence on tourism development, Tourism Management, 34, pp. 145-157, 2013.

[4] Hall, C. M. \& O’Sullivan, V. Tourism, political stability and violence. In: A. Pizam, \& Y. Mansfeld (Eds.), Tourism, crime and international security issues (pp. 105-121). NY: Willey, 1996.

[5] Hall, C. M. Space-time accessibility and the TALC: The role of geographies of spatial interaction and mobility in contributing to an improved understanding of tourism. In R. Butler (Ed.), The tourism area life cycle, Vol. 2: Conceptual and theoretical issues (pp. 83-100). Clevedon: Channel View, 2006.

[6] Hovinen, G. R. Revisiting the destination lifecycle model, Annals of Tourism Research, 29(1), pp. 209-230, 2002.

[7] Jenkins, C. L. \& Henry, B. M. Government involvement in tourism in developing countries, Annals of Tourism Research, 9(4), pp. 499-521, 1982.

[8] Lozano, J., Gomez, C. \& Rey-Maquieira, J. The TALC hypothesis and economic growth, Tourism Economics, 14(4), 727-749, 2008.

[9] Papatheodorou, A. TALC and the spatial implications of competition. In R. Butler (Ed.), The tourism area life cycle, Vol. 1: Applications and modifications (pp. 67-82). Clevedon: Channel View, 2006.

[10] Russel, R. The contribution of entrepreneurship theory to the TALC model. In Butler, R. (Ed). The Tourism Area Life Cycle: Conceptual and theoretical issues (pp. 105-123), Channel View Publications, 2011.

[11] Rink, D. R. \& Swan, J. E. Product life cycle research: A literature review, Journal of Business Research, 7(3), pp. 219-242, 1979.

[12] Weaver, D. The 'plantation' variant of the TALC in the small-island Caribbean. In R. Butler (Ed.), The tourism area life cycle, Vol. 1: Applications and modifications (pp. 185-197). Clevedon: Channel View, 2006. 